\title{
The 4G/5G Polymorphism in the Plasminogen Activator Inhibitor-1 Gene Is not Associated with Myocardial Infarction
}

\author{
C. J. M. Doggen', R. M. Bertina ${ }^{2}$, V. Mànger Cats' ${ }^{3}$, P. H. Reitsma ${ }^{2}$ * , F. R. Rosendaal ${ }^{1,2}$ \\ From the 'Department of Clinical Epidemiology, Lêiden Universıty Medical Center, The Netherlands \\ ${ }^{2}$ Hemostasis and Thrombosis Research Center, Leiden University Medical Center, The Netherlands \\ ${ }^{3}$ Department of Cardiology, Leiden University Medical Center, The Netherlands
}

\section{summary}

Sereral studies have found an association between high plasminosn activator inhibitor-1 (PAI-1) levels and myocardial infarction. Whether this is causal or a consequence of atherosclerosis or tissue damage. remains unclear. Homozygous carriers of the $4 \mathrm{G}$ allele of the $\$ \mathrm{G} / 5 \mathrm{G}$ polymorphism in the PAI-1 gene have higher PAI- 1 levels compared to carriers of the $5 \mathrm{G}$ allele in healthy persons in some studies, but not all. If PAI-1 levels are causally related to myocardial infarction, one would expect more homozygous carriers of the $4 \mathrm{G}$ allele among paunts. provided that these carriers have high PAI-1 levels among healthy persons in that population. We investigated the distribution of this poIymorphism in the "Study of Myocardial Infarctions Leiden" (SMILE), including 331 men with a myocardial infarction and 302 control wbjects and measured PAI- 1 antigen levels among the latter. Secondly, we looked into the association of cardiovascular risk factors with PAl-1 levels.

We did not find an increase in risk of myocardial infarction in carrien of the $4 \mathrm{G}$ allele. Neither did we find an association, nor a trend, hetween the $4 \mathrm{G} / 5 \mathrm{G}$ polymorphism and PAI-1 antigen levels in control subjects. Controls with obesity, hypertension, or who smoked had sigmficant higher PAI-1 antigen levels compared with persons without these factors. High cholesterol and triglyceride levels were also assocnted with high PAI-1 antigen levels, and HDL-cholesterol levels showed an inverse association.

We conclude that the $4 \mathrm{G} / 5 \mathrm{G}$ polymorphism in the PAI- 1 gene is not associated with the risk of myocardial infarction. As we did not find any association between this polymorphism and PAI-1 antigen levels in healthy persons, we cannot draw any conclusions about the causality of PAl-l itself for myocardial infarction.

\section{Introduction}

Plasminogen activator inhibitor-1 (PAI-1) is the major rapid inhibitor of tissue type plasminogen activator (t-PA) (1). t-PA itself is a physiologic activator of fibrinolysis. PAI-1 deficiency in a child led to a hemorraghic diathesis (2). A Swedish study suggested that reduced fibrinolytic capacity due to increased plasma levels of a rapid inhibitor of t-PA is important in the pathogenesis of myocardial infarction (3).

Correspondence to: Prof. Dr. F. R. Rosendaal, Dept of Clinical Epidemiology, Bidg 1 CO-P, Leiden University Medical Center, P.O. Box 9600, 2300 RC Leiden, The Netherlands - Tel.: +31-71-5264037; FAX Number: +31.71-5248122; E-mail: Rosendaal@rullf2.medfac.leidenuniv.nl

* Present address: Dr. P. H. Reitsma, Laboratory for Experimental Internal Medicine. Academic Medical Center, Amsterdam, The Netherlands
High plasma levels of PAI-1 were independently related to reinfarction within 3 years in 109 men who had survived a myocardial infarction before the age of 45 (4), but not to late reinfarction in a follow-up of 6-years among 127 consecutive young men (5). Since 1985, several case-control studies found a positive association between plasma levels of PAI-1 activity and antigen, and the risk of myocardial infarction (3, 6-11). Other large studies found no association (12-14). At best, the association between PAI-1 levels and the risk for myocardial infarction is equivocal. And even if there is truly an association between PAI-1 levels and myocardial infarction, this still does not allow the conclusion of a causal-and-effect relationship between PAI-1 and the risk of myocardial infarction, because of the following complicating factors.

The first issue, which exists even in prospective studies, is the effect of atherosclerosis. If atherosclerosis increases PAI- 1 levels, these levels themselves are not a causal risk factor for myocardial infarction, but rather a marker of atherosclerosis. This is not inconceivable as several studies showed preclinical atherosclerosis levels to be associated with elevated PAI-1 antigen and activity levels (15-17). Increased PAI-1 mRNA levels were found in atherosclerotic human arteries which supports the hypothesis of PAI-1 levels being a marker of atherosclerosis (18). The second issue regards the effect of myocardial infarction on PAI-1 levels and appears in cross-sectional and case-control studies. Myocardial infarction is accompanied by tissue damage which may stimulate the production of PAI-1. Elevations in PAI-1 may therefore be a consequence of the disease and not a causal factor. The third issue concerns confounding by cardiovascular risk factors, such as obesity which is known to be related to PAI-1 levels (19) and is simultaneously a risk factor for myocardial infarction.

These difficulties are avoided in a study in which one examines the distribution of a genetic variation of the PAI-1 gene, known to be related to PAI- 1 levels in healthy persons. If PAI-1 itself is a causal risk factor, patients with myocardial infarction will more often have the genotype which causes high levels of PAI-1, compared to healthy persons. In this way, we circumvent the problem of atherosclerosis and confounding.

In several studies, the $4 \mathrm{G} / 5 \mathrm{G}$ polymorphism in the promoter of the PAI-1 gene was related to plasma PAI- 1 activity and antigen levels in healthy persons. Individuals homozygous for the $4 \mathrm{G}$ allele had increased PAI-1 levels compared to other individuals with at least one $5 \mathrm{G}$ allele (20-27).

In this paper we first present the results of the population-based case-control "Study of Myocardial Infarctions Leiden" (SMILE) with respect to the relationship between the $4 \mathrm{G} / 5 \mathrm{G}$ polymorphism of the PAI-1 gene and myocardial infarction among 331 men with a first myocardial infarction and 302 controls. Secondly, PAI-1 antigen levels measured in control subjects and the association with the $4 \mathrm{G} / 5 \mathrm{G}$ polymorphism of the $\mathrm{PAI}-1$ gene and several cardiovascular risk factors are presented. 


\section{Materials and Methods}

\section{Paftents and Control Subjects}

Patıents were 331 men with a first myocardial infarction between January 1990 and November 1994, who were below the age of 70 . They participated in the population-based case-control "Study of Myocardial Infarctions Leiden" (SMILE). Two of the following thrce characteristics had to be present in the discharge report or hospital chart to confirm acute myocardial infarction: typical chest pain, electrocardiographic changes typical for myocardial infarction and a transient rise in cardiac enzymes to more than twice the upper limit of normal.

Control subjects were 302 men who had undergone an orthopedic intervention between January 1990 and June 1994, for which they had routinely received prophylactic anticoagulants for a short period. Control subjects were excluded if they had a history of myocardial infarction or had used oral anticoagulants in a 6-month period prior to participation in this study.

Both cases and control subjects were living in the Leiden area and were born in the Netherlands. Excluded were men with renal disease, severe (neuro) psychiatric problems, or a life expectancy less than one year. Every individual completed a questionnaire concerning the presence of cardiovascular risk factors such as smoking and alcohol consumption. For patients all questions referred to the period before their myocardial infarction. The quetelet index was derived by dividing weight (kilograms) by squared height (meters ${ }^{2}$ ). Persons were considered obese if their quetelet index exceeded $30 \mathrm{~kg} / \mathrm{m}^{2}$. Medication use and presence of diabetes were ascertained in an interview with controls and retrieved from discharge letters of patients. A person was classified as hypertensive or hypercholesterolemic when he was taking specific prescription drugs. Full details of the study SMILE have been published elsewhere (28).

\section{Blood Collection, DNA Analsis}

and Plasminogen Activator Inhbitor-I Antigen Assay

Morning fasting blood samples were drawn from the antecubital vein with the person in an upright position. 20 Persons of which a blood sample was drawn, did not fast. Blood in the first tube was allowed to clot and the serum was used for measuring total cholesterol. HDL-cholesterol and triglyceride levels. Following bloodsamples were drawn in two Sarsted Monovette ${ }^{\mathrm{R}}$ tubes containing $0.106 \mathrm{mM}$ trisodium citrate. We used the cells collected after centrifugation of the blood samples, for DNA extraction. The last blood sample was drawn in a CTAD tube (Diatube $\mathrm{H}$, Becton Dickinson) for measurement of PAI- 1 antigen and immediately put on ice. Blood of this CTAD tube was centrifuged for $20 \mathrm{~min}$ at $3000 \mathrm{~g}$ at $4^{\circ} \mathrm{C}$, after which plasma was aliquoted in two tubes, snap frozen and stored at $-80^{\circ} \mathrm{C}$. The median time between myocardial infarction or orthopedic intervention and blood collection were 3.5 years (range 0.7 to 5.7 years) and 2.9 years (range 0.6 to 6.0 years) respectively.

High molecular weight DNA was extracted from the white blood cells by a salting-out method (29). The DNA was stored at $4^{\circ} \mathrm{C}$. Amplification of a fragment of the PAI-I gene was performed using the technique of polymerase chain reaction $(\mathrm{PCR})$ with $1 \mu$ genomic DNA and 0.2 units thermostable Taq DNA polymerase (Perkin Elmer, New Jersey, USA) in a Barnstead thermocycler (Biomed $\mathrm{GmbH}$, West-Germany). The nucleotide sequence of the mutant primer at 5' site and the primer at the 3' site were respectively: 5'- GCC CTC AGG GGC ACA GAG AGA GTC TGG CCA-3' and 5'- GCA ATG CAG CCA GCC ACG TG-3'. The initial cycle consisted of a step at $90^{\circ} \mathrm{C}$ for $4 \mathrm{~min}$; this was followed by $30 \mathrm{cycli}$ of $93^{\circ} \mathrm{C}$ for $60 \mathrm{sec}, 58^{\circ} \mathrm{C}$ for $60 \mathrm{sec}$ and $70^{\circ} \mathrm{C}$ for $3 \mathrm{~min}$. This results in a fragment of about $163 \mathrm{bp}$, which is part of the promoter of the PAI-1 gene. This fragment includes the $4 \mathrm{G} / 5 \mathrm{G}$ polymorphism, a single guanosine deletion / insertion variation, 675 base pairs upstream from the start of transcription of the PAI-1 gene, which is located at chromosome 7 (q21.3 - q22) (30). $5 \mu$ l of the PCR reactions were digested with 1 unit of Bsll restriction enzyme (Biolabs, New England) for $2 \mathrm{~h}$ at $55^{\circ} \mathrm{C}$. DNA fragments were separated by electrophoresis on $2 \%$ agarose gels. The allele coding for $4 \mathrm{G}$ gave fragments of $107 \mathrm{bp}$ and $56 \mathrm{bp}$. The allele coding for $5 \mathrm{G}$ gave fragments of $74 \mathrm{bp}, 56 \mathrm{bp}$ and $34 \mathrm{bp}$. Each individual was classified into one of the three genotypes: $4 \mathrm{G} / 4 \mathrm{G}, 4 \mathrm{G} / 5 \mathrm{G}$ or $5 \mathrm{G} / 5 \mathrm{G}$.
Total cholesterol and triglyceride concentrations were measured using enzymatic assays adapted to a Hitachi 747 (Boehringer Mannheim), and high density lipoprotein (HDL)-cholesterol concentration was measured on a Hitachi 911 (Boehringer Mannheim).

PAI-1 antigen was measured in control subjects with an enzyme immunoassay, Biopool Imulyse ${ }^{R}$ PAI-1 (Kordia, the Netherlands). In four control subjects PAI- 1 antigen levels measurements were not performed for practical reasons. According to the manufacturer the intra assay coefficient of variation was $5 \%$, the inter assay coefficient was found to be $8.1 \%$. Four individuals in whom extremely high levels of PAI- $\mathrm{I}$ antigen $(\geq 200 \mathrm{ng} / \mathrm{ml}$ ) were measured and who did not have obesity or diabetes were excluded from the statistical analyses. Thus, in the analyses of PAI-1 antigen leveIs 294 control subjects were included.

\section{Statistical Analysis}

Allele frequencies in the cases and control subjects were compared by allele counting and chi-square analysis. The expected genotype distribution was computed using the Hardy-Weinberg equation under equilibrium assumptions. A chi-square test was used to compare the observed numbers of each genotype with those expected for a population in Hardy-Weinberg equilibrium. An odds ratio $(\mathrm{OR})$ was calculated as a measure of relative risk. A $95 \%$ confidence interval $(95 \% \mathrm{CI})$ was calculated according to the method of Woolf (31) or by using the standard errors of the parameter calculated by logistic regression. Multiple logistic regression was performed to adjust for age. As the PAI-1 antigen level was not normally distributed $10 \mathrm{log}$ transformation was applied. These $\log$ transformed values were used in analyses. The PAI-1 antigen levels are presented as geometric means with the appropriate standard deviation (sd) or $95 \%$ confidence intervals (CI). Univariate one-way analyses of variance (ANOVA) was used when comparing groups concerning a continuous variable Distributions of categorical variables were compared by means of the chisquare test. Differences were considered significant at a p-value of $<.05$. The contribution of various variables to PAI-1 antigen levels was assessed by multiple linear regression analysis. The model with the highest $F$-value was considered as the best model, i. c. explaining most of the variance of PAI-1 antigen levels.

\section{Results}

\section{$4 G / 5 G$ Polymorphism of PAI-1 Gene among Patients and Control} Subjects

The characteristics of the 331 patients and 302 control subjects are shown in Table 1. The mean age of patients was 56.1 (sd 9.0) years compared to 52.9 (sd 12.0) years in control subjects. Established cardiovascular risk factors such as smoking and hypertension were present, more often in patients (respectively $63.1 \%$ and $21.5 \%$ ) than in control subjects $(39.4 \%$ and $12.6 \%)$. In men under the age of 50 , these differences were even more pronounced.

The $4 \mathrm{G}$ allele frequency was $0.52(\mathrm{CI} 0.47-0.57)$ among patients and 0.53 (Cl 0.47 - 0.59) among control subjects. The distribution of genotypes in both groups was as expected for a sample in Hardy-Weinberg equilibrium. As shown in Table 2, the relative risks of myocardial infarction for homozygous and heterozygous carriers of the $4 \mathrm{G}$ allele were not increased when compared to homozygous carriers of the $5 \mathrm{G}$ allele, with odds ratios at or close to unity. Adjustment for age did not affect these results.

In the subgroup of 311 men aged less than 50 years, the $4 \mathrm{G}$ allele frequency was 0.56 (CI $0.49-0.63$ ) among patients and 0.53 (CI 0.46 0.59 ) among control subjects. The risk for homozygous carriers of the $4 \mathrm{G}$ allele compared to homozygous carriers of the $5 \mathrm{G}$ allele was $1.3-$ fold increased, though not significantly (OR, 1.3; 95\% CI, $0.6-2.9$ ), while for heterozygous carriers no increased risk was found $(\mathrm{OR}, 1.0$; $95 \% \mathrm{Cl}, 0.5-2.1)$. No differences between genotype distributions were found for men aged 50 years or above, with a frequency of the $4 \mathrm{G}$ al- 
Tutel Charactenstics of patients* and control subjects in the Study of Vycxardial Infartions Leiden'

\begin{tabular}{|c|c|c|c|c|}
\hline & \multicolumn{2}{|c|}{ Overal! } & \multicolumn{2}{|c|}{$<50$ years } \\
\hline & 331 cases & 302 controls & 91 cases & 120 controls \\
\hline $4 x \operatorname{mean}(x d)$ & $561(90)$ & $529(120) \dagger$ & $442(44)$ & $406(68) \dagger$ \\
\hline Cuerent Smokers (\%) & $209(631)$ & $119(394) \ddagger$ & $70(769)$ & $53(442) \ddagger$ \\
\hline terbol users (\%) & $258(779)$ & $264(874) \ddagger$ & $81(890)$ & $105(875)$ \\
\hline$(x+4 t)\left(*_{0}\right) \S$ & $54(163)$ & $48(159)$ & $20(220)$ & $18(150)$ \\
\hline Deabetes (\%) & $11\left(\begin{array}{ll}3 & 3\end{array}\right)$ & $7(23)$ & $4(44)$ & $1(08)$ \\
\hline Uivertension (\%)** & $71(215)$ & $38(126) \ddagger$ & $28(308)$ & $17(142) \ddagger$ \\
\hline Hipertholesterolemia (\%)** & $5(15)$ & $6(20)$ & $2(22)$ & $1(08)$ \\
\hline
\end{tabular}

- usu refer to period prior to myocardial infarction except for age and obesity

AHova, p-vajue< 005

D. His square test $p$-value 005

f wesuly is present as the quetelet index exceeds $30 \mathrm{~kg} / \mathrm{m}^{2}$

" a person was classified as having hypertension or hypercholesterolemıa if the was takıng

prific prescription drugs

kle of 052 in both patients and control subjects The distribution of ge notypes in both patients and control subjects in the younger and older group was as expected for a sample in Hardy Weinberg equilibrium

Among non-smokers, the odds ratios adjusted for age were for ho mozygous carriers of the $4 \mathrm{G}$ allele $16(95 \% \mathrm{CI}, 08-31)$ and for he-

Table 2 Distribution of genotype of the $4 \mathrm{G} / 5 \mathrm{G}$ polymorphism of the plasm wogen autivator inhibitor-1 gene in patients and control subjects

\begin{tabular}{|c|c|c|c|}
\hline Getrotype & $\begin{array}{l}\text { Cases } \\
N(\%)\end{array}$ & $\begin{array}{l}\text { Controls } \\
N(\%)\end{array}$ & Odds ratio $(95 \% \mathrm{CI})^{*}$ \\
\hline $5 \mathrm{G} / 5 \mathrm{G}$ & $73(221)$ & $68(225)$ & $10 t$ \\
\hline$+C / S G$ & $170(514)$ & $150(497)$ & $11(07 \quad 16)$ \\
\hline $4 G / 4 G$ & $88(266)$ & $84(278)$ & $10(06 \quad 15)$ \\
\hline Total & 331 & 302 & \\
\hline
\end{tabular}

$\begin{array}{cccc}\text { < } 30 \text { years } & & & \\ \text { SG/5G } & 18(198) & 26(217) & 10 \dagger \\ 4 G / 5 G & 44(484) & 62(517) & 10(05-21) \\ 4 G / 4 G & 29(319) & 32(267) & 13(0629) \\ \text { Total } & 91 & 120 & \end{array}$

\begin{tabular}{|c|c|c|c|}
\hline $5 \mathrm{G} / 5 \mathrm{G}$ & $55(229)$ & $42(231)$ & $10 \dagger$ \\
\hline $4 \mathrm{G} / 5 \mathrm{G}$ & $126(525)$ & $88(484)$ & $11(07-18)$ \\
\hline $4 G / 4 G$ & $59(246)$ & $52(286)$ & $09(05 \quad 15)$ \\
\hline Total & 240 & 182 & \\
\hline
\end{tabular}

- ratios of $4 \mathrm{G} / 4 \mathrm{G}$ or $4 \mathrm{G} / 5 \mathrm{G}$ versus $5 \mathrm{G} / 5 \mathrm{G}$ with $95 \%$ confidence interval

inference category $5 \mathrm{G} / 5 \mathrm{G}$
Table 3 Plasmınogen activator inhibitor 1 (PAI 1) antigen levels in control subjects according to genotype of the $4 \mathrm{G} / 5 \mathrm{G}$ polymorphism of the PAI I gene

\begin{tabular}{|c|c|c|c|}
\hline Genotype & $\mathrm{N}(\%)$ & $\begin{array}{c}\text { PAI } 1 \text { antigen } \mathrm{ng} / \mathrm{ml} \\
\text { Mean (sd) }\end{array}$ & P value * \\
\hline $5 \mathrm{G} / 5 \mathrm{G}$ & $64(218)$ & $145(28)$ & 04 \\
\hline $4 \mathrm{G} / 5 \mathrm{G}$ & $146(497)$ & $169(23)$ & \\
\hline $4 G / 4 G$ & $84(286)$ & $150(21)$ & \\
\hline Total & $294 \dagger$ & $158(24)$ & \\
\hline \multicolumn{4}{|c|}{$\begin{array}{l}{ }^{*} \mathrm{p} \text { value of ANOVA comparing log transformed plasminogen activator inhibitor } 1 \text { level } \\
\text { between three genotypes } \\
\dagger \text { in four persons PAI } 1 \text { antigen levels were not measured and four persons were exclude }\end{array}$} \\
\hline
\end{tabular}

Table 4 Association between plasminogen activator inhibitor 1 antigen levels and cardiovascular risk factors in control subjects

\begin{tabular}{|c|c|c|c|}
\hline \multirow{2}{*}{$\begin{array}{c}\text { Cardiovascular risk } \\
\text { factor }\end{array}$} & \multicolumn{3}{|c|}{ PAl I antigen (ng/ml) } \\
\hline & $\mathrm{N}$ & Mean (CI) & P value* \\
\hline Overall & $294 \dagger$ & $158(143 \quad 174)$ & \\
\hline \multicolumn{4}{|l|}{ Smoking } \\
\hline Never & 48 & $118(98-141)$ & 033 \\
\hline Former & 130 & $171(146 \quad 200)$ & \\
\hline Current & 116 & $164(140-192)$ & \\
\hline \multicolumn{4}{|l|}{ Alcohol } \\
\hline Never & 24 & $130(93 \quad 181)$ & 057 \\
\hline Occasıonally & 13 & $99(57-172)$ & \\
\hline Regularly & 257 & $165(148-183)$ & \\
\hline \multicolumn{4}{|l|}{ Obesity } \\
\hline Absent & 248 & $137(124-152)$ & $<001$ \\
\hline Present & 46 & $336(274 \quad 411)$ & \\
\hline \multicolumn{4}{|l|}{ Drabetes } \\
\hline Absemt & 288 & $158(143 \quad 174)$ & 980 \\
\hline Present & 6 & $157(58-424)$ & \\
\hline \multicolumn{4}{|l|}{ Hypertension } \\
\hline Absent & 256 & $151(136-167)$ & 015 \\
\hline Present & 38 & $217(167-281)$ & \\
\hline \multicolumn{4}{|l|}{ Hypercholesterolemıa } \\
\hline Absent & 288 & $157(142 \quad 173)$ & 382 \\
\hline Present & 6 & $214(142 \quad 323)$ & \\
\hline
\end{tabular}

${ }^{t} \mathrm{p}$ value of ANOVA comparing $\log$ transformed plasminogen activator inhibitor 1 levels

$\dagger \mathrm{m}$ four persons PAI 1 antigen levels were not measured and four persons were excluded because they had extremely high levels $(\geq 200 \mathrm{ng} / \mathrm{ml}$ ) Of this group three men were current smokers seven were regularly alcohol users two had obesity and one person had drabetes which explains the difference in numbers with Table 1

terozygous carriers $19(95 \% \mathrm{Cl}, 10-35)$ compared to carriers homozygous for the $5 \mathrm{G}$ allele In contrast, among smokers these odds ratios were respectively 07 (95\% CI, $04-13$ ) and 07 (95\% Cl, $04-14)$ Restriction of the analysis to men without obesity, diabetes, hypertensi on or hypercholesterolemia, did not change the overall odds ratios presented in Table 2 ( 1 e at or very close to unty) 
Table 5 Tertiles of cholesterol, HDL-cholesterol and triglycendes and the association with plasmınogen activator inhibitor-1 antigen levels in control subjects

\begin{tabular}{|c|c|c|}
\hline Tertiles & $\begin{array}{c}\text { PAl-1 antigen }(\mathrm{ng} / \mathrm{ml}) \\
\text { Mean }(\mathrm{CI})\end{array}$ & P-value* \\
\hline \multicolumn{3}{|c|}{ Total cholesterol (mmo/l/) } \\
\hline $233-539$ & $122(103-143)$ & $<001$ \\
\hline $540-628$ & $169(139-205)$ & \\
\hline $629-1058$ & $193(166-224)$ & \\
\hline \multicolumn{3}{|c|}{ Triglyceride levels (mmol/l) } \\
\hline $035-105$ & $103(88-120)$ & $<001$ \\
\hline $106-168$ & $146(124-172)$ & \\
\hline $169-959$ & $263(228-304)$ & \\
\hline \multicolumn{3}{|c|}{ HDL-cholesterol $(\mathrm{mmo} / \mathrm{l})+$} \\
\hline $062-115$ & $219(185-258)$ & $<001$ \\
\hline $116-137$ & $152(129-179)$ & \\
\hline $138-245$ & $119(100-140)$ & \\
\hline
\end{tabular}

* p-value of ANOVA comparing log transformed plasminogen activator inhibitor-1 levels

$\dagger$ two missing values

\section{PAI-I Antigen Level, 4G/5G Polymorphism and Cardiovascular Risk Factors among Control Subjects}

The mean PAI-1 antigen level in 294 healthy controls was 15.8 (sd $2.4 \mathrm{ng} / \mathrm{ml}$ ), without any statistical difference between genotypes (Table 3). Six individuals had a PAI-1 antigen level above $100 \mathrm{ng} / \mathrm{ml}$. The results did not change when restriction was made to levels under the 100 $\mathrm{ng} / \mathrm{ml}$, nor did exclusion of individuals with known obesity, diabetes, hypertension or hypercholesterolemia affect the results.

Control subjects below the age of 50 years had mean PAI-1 antigen levels of 15.7 (sd 2.4) ng/ml, not significantly different from control subjects of 50 years of age or above, i.e. 15.8 (sd 2.4) ng/ml. In Table 4 it is shown that PAI-1 antigen levels were higher among smokers and former smokers compared to non-smokers $(p=.033)$, and levels seemed to be higher among men using alcohol regularly $(p=.057)$. Only 6 persons had diabetes or hypercholesterolemia and did not show any statistical difference in PAI-1 antigen levels compared to persons without these cardiovascular risk factors. The presence of obesity in 46 individuals was associated with high PAI-1 antigen levels of 33.6 (CI 27.4 $41.1) \mathrm{ng} / \mathrm{ml}$ compared to 248 persons without obesity (13.7 (CI 12.4 $15.2) \mathrm{ng} / \mathrm{ml})(\mathrm{p}<.001)$. Hypertension in 38 control subjects was associated with a mean PAI-1 level of 21.7 (CI $16.7-28.1$ ) ng/ml, which was considerably higher than in 256 persons without hypertension $(15.1$ [Cl $13.6-16.7] \mathrm{ng} / \mathrm{ml})(\mathrm{p}=.015)$. All lipids showed a significant association with PAI-1 antigen levels (all $\mathrm{p}<.001$ ); high cholesterol and triglyceride levels were associated with high PAI-1 antigen levels, and HDL-cholesterol levels showed an inverse association (Table 5). The associations between lipids and PAI-1 antigen levels were independent of the $4 \mathrm{G} / 5 \mathrm{G}$ polymorphism.

Multiple linear regression was performed with PAI-1 antigen level as the dependent and age, smoking, alcohol use, quetelet index, diabetes, hypertension, (HDL-) cholesterol levels and triglyceride levels as independent variables in various combinations. The model including both age, triglyceride levels and quetelet index explained much of the variance of $\mathrm{PAI}-1$ antigen levels, i. e. $39.2 \%$. The $4 \mathrm{G} / 5 \mathrm{G}$ polymorphism did not contribute to this variance.

\section{Discussion}

We found no association between the $4 \mathrm{G} / 5 \mathrm{G}$ polymorphism of the PAI-1 gene and risk of myocardial infarction. The polymorphism was not related to levels of PAI-1 antigen in healthy men. Former or current smokers, and persons with obesity or hypertension had significant higher PAI-1 antigen levels than those without these cardiovascular risk factors. Both total cholesterol and triglyceride levels were positively, and HDL-cholesterol inversely associated with PAI-1 antigen levels.

Our results confirm those of the Physicians' Health Study (PHS), a cohort study including men aged 40-84 years, where no association was present between the $4 \mathrm{G} / 5 \mathrm{G}$ polymorphism of the PAI-1 gene and myocardial infarction and where similar allele frequencies were found (32). The results of our and other studies $(22,32,33)$ contrast with those of a study among 453 patients admitted for investigation of chest pain or suspected coronary artery disease and with those of a Swedish casecontrol study. In the former study, the frequency of the $4 \mathrm{G} / 4 \mathrm{G}$ genotype was higher among patients with a history of myocardial infarction (34). In the latter study, which included 93 men with a first myocardial infarction before the age of 45 , the $4 \mathrm{G} / 4 \mathrm{G}$ genotype conferred a twofold increased risk of myocardial infarction compared to carriers of the $5 G$ allele $(\mathrm{OR}, 2.15 ; 95 \% \mathrm{CI}, 1.17-3.96)$ (21). Restriction to men under the age of 50 in our study SMILE did not confirm these results.

We found no association between genotypes of the $4 \mathrm{G} / 5 \mathrm{G}$ polymorphism of the PAI-1 gene and PAI-1 antigen levels in healthy men, which agrees with the results of several studies $(23,35)$, but is in disagreement with others $(24-27,36)$. A possible explanation for these different results is that in some populations, but not ours, the $4 \mathrm{G} / 5 \mathrm{G}$ polymorphism of the PAI-1 gene is in linkage disequilibrium with a true causal mutation affecting PAI-1 levels. Another possibility is a difference in triglyceride levels between populations. In vitro experiments have shown that both alleles of the $4 \mathrm{G} / 5 \mathrm{G}$ polymorphism contain a binding site for a transcriptional activator $(\mathrm{A})$, and that the $5 \mathrm{G}$ allele also contains a binding site for a transcriptional repressor $(R)$ that partially overlaps with the A-binding site. Therefore, in the presence of the repressor $(\mathrm{R})$, it is expected that the $4 \mathrm{G}$ allele is associated with increased basal gene transcription $(20,37,38)$. More recently, a VLDL response element has been identified, which acts as an activator and is located adjacent to and partly overlaps with the repressor (R)-binding site on the $5 \mathrm{G}$ allele. Competition between the transcriptional repressor and the VLDL-induced factor for binding to the $5 \mathrm{G}$ allele, may explain the 4G/5G allele specific relation between VLDL triglyceride and PAI-1 levels in plasma (38). However, it is not known to what extent increasing triglyceride levels will result in removal of the repressor of PAI- 1 transcription from the $5 \mathrm{G}$ allele and how this will affect plasma PAI-1 antigen levels. It is noted though, that in patients with existing coronary atheroma or with non-insulin-dependent diabetes mellitus homozygous carriers of the $4 \mathrm{G}$ allele had very high PAI-1 antigen levels in the presence of high triglyceride levels, compared to homozygous carriers of the $5 \mathrm{G}$ allele (39). In our control group, that on average will have less atherosclerosis, such a relationship was not observed; no differences in the association of PAI-1 antigen with triglyceride levels between genotype's were found. Other studies among healthy persons reported similar findings $(22,24,35,36,40)$.

Smokers and men using alcohol had higher PAI-1 antigen levels compared to men without these risk factors, which is also reported in an Italian study among subjects without clinical atherosclerosis (36). This 
is in contrast, however, to several other studies $(24,26,35)$. No differences in PAI-1 antigen levels were found between men with or without diabetes or hypercholesterolemia, though numbers were small, whereas a significant difference was found depending on the presence of obesiIf or hypertension. Consistent with the results of other studies high triglyceride levels were associated with high PAI-1 antigen levels (14, $26,35,36,40)$, as were high cholesterol levels $(35,36)$. The negative association between PAI-1 antigen levels and HDL-cholesterol has been described before in patients with angina pectoris (14). The $4 \mathrm{G} / 5 \mathrm{G}$ polymorphism of the PAI-1 gene had no significant contribution to PAI-I antigen variability, as was found in healthy men in the Stanislas cohort study (24). In an Italian study the contribution of this polymorphism to PAI-1 antigen levels was small (36). The association of PAI1 antigen levels with several cardiovascular risk factors could explain why several studies found a relation between PAI-1 levels and myocardial infarction $(3,6-11)$, and others after adjustment for several of these risk factors did not $(13,14)$.

We conclude that the $4 \mathrm{G} / 5 \mathrm{G}$ polymorphism of the PAI- 1 gene is not related to myocardial infarction. As we did not find any association between this polymorphism and PAI-1 antigen levels in healthy persons, we cannot draw any conclusions about the causality of PAI-1 itself for myocardial infarction.

\section{Acknowledgements}

The authors wish to thank the cardiologists of the Departments of Cardiology from the Leiden University Medical Center and the general Hospital Diaconessenhuis Leiden, and F. J. M. van der Meer, head of the Leiden Anticoagulant Clinic. H. L. Vos, molecular biologist from the Hemostasis and Thrombosis Research Center gave us very useful comments on the discussion. We particularly would like to thank our laboratorium technician Mrs T.Visser for performing the DNA analysis and assay for the PAI-1 antigen levels. For secretarial and administrative support we are indebted to Mrs J. J. Schrcijer. We also express our gratitude to all individuals who participated in "Study of Myocardial Infarctions Leiden". This research was supported by the Netherlands Heart Foundation (Grant no. 92.345).

\section{References}

I. Rijken DC. Plasminogen activators and plasminogen activator inhibitors: biochemical aspects. Baillière Clin Haem 1995; 8: 291-312.

2. Fay WP, Shapiro AD, Shih JL, Schleef RR, Ginsburg D. Brnef report: complete deficiency of plasminogen-activator inhibitor type 1 due to a frameshift mutation. N Engl J Med 1992; 327: 1729-33.

3. Hamsten A, Wiman B, De faire U, Blombäck M. Increased plasma levels of a rapid inhibitor of tissue plasminogen activator in young survivors of myocardial infarction. N Engl J Med 1985; 313: 1557-63.

4. Hamsten A, De faire U, Walldius G, Dahlén G, Szamosi A, Landou C, Blombäck M, Wiman B. Plasminogen activator inhibitor in plasma: risk factor for recurrent myocardial infarction. Lancet 1987; II: 3-9.

5. Wiman B, Hamsten A. The fibrinolytic enzyme system and its role in the etiology of thromboembolic disease. Semin Thromb Hemost 1990; 16: 207-16.

6. Hamsten A, Blombäck M, Wiman B, Svensson J, Szamosi A, De faire U, Mettinger $L$. Haemostatic function in myocardial infarction. Brit Hearl $\mathrm{J}$ 1986; 55: 58-66.

7. Almér L, Öhlin H. Elevated levels of the rapid inhibitor of plasminogen activator (t-PAI) in acute myocardial infarction. Thromb Res 1987; 47: 335-9.

8. Dawson S, Henney A. The status of PAI-1 as a risk factor for arterial and thrombotic disease: a review. Atherosclerosis 1992; 95; 105-17.

9. Gray RP, Patterson DLH, Yudkin JS. Plasminogen activator inhibitor activity in diabetic and nondiabetic survivors of myocardial infarction. Arterioscl Thromb 1993; 13: 415-20.
10. Lowe GDO, Rumley A, Balendra R, Lee AJ, Tunstall-Pedoe H. Blood rheology and haemostasis in survivors of premature myocardial infarction: a case-control study. Thromb Haemost 1993; 69: 763.

11. Chandler WL, Stratton JR. Laboratory evaluation of fibrinolysis in patients with a history of myocardial infarction. Am J Clin Pathol 1994; 102: 248-52.

12. Ridker PM, Vaughan DE, Stampfer MJ, Manson JE. Hennekens CH. A prospective study of plasminogen activator inhibitor and the risk of future myocardial infarction. Circulation 1992; 86: I-325.

13. Lowe GDO, Yarnell JWG, Sweetnam PM, Rumley A, Thomas HF, Elwood $P C$. Fibrin D-dimer, tissue plasminogen activator, plasminogen activator inhibitor, and the risk of major ischaemic heart disease in the Caerphilly study. Thromb Haemost 1998; 79: 129-33.

14. Juhan-Vague I, Pyke SDM, Alessi MC, Jespersen J, Haverkate F. Thompson SG. Fibrinolytic factors and the risk of myocardial infarction or sudden death in patients with angina pectors. Circulation 1996; 94: 2057-63.

15. Salomaa V, Stinson V, Kark JD, Folsom AR, Davis CE, Wu KK. Association of fibrinolytic parameters with early atherosclerosis. The ARIC study. Circulation 1995; 91: 284-90.

16. Smith FB, Lee AJ, Rumley A, Fowkes FGR, Lowe GDO. Tissue-plasminogen activator, plasminogen activator inhibitor and risk of peripheral arterial disease. Atherosclerosis 1995; 115: 35-43.

17. Folsom AR, Pankow JS, Williams RR, Evans GW, Province MA, Eckfeldt $\mathrm{JH}$. Fibrinogen, plasminogen activator inhibitor-1. and carotid intima-media wall thickness in the NLHBI family heart study. Thromb Haemost 1998; 79: 400-4.

18. Schneiderman J, Sawdey MS. Keeton MR. Bordin GM, Bernstein EF, Dilley RB, Loskutoff DJ. Increased type 1 plasminogen actıvator inhibitor gene expression in atherosclerotic human arterıes. Proc Natl Acad ScI USA 1992; 89: 6998-7002.

19. Juhan-Vague I. Alessi MC. PAl-l, obesity. insulin resistance and risk of cardıovascular events. Thromb Haemost 1997; 78: 656-60.

20. Dawson SJ, Wiman B, Hamsten A, Green F. Humphries S, Henney AM. The two allele sequences of a common polymorphism in the promoter of the plasminogen activator inhibitor-1 (PAI-1) genc respond differently to interleukin-1 in HepG2 cells. J Biol Chem 1993: 268 (15): 10739-45.

21. Eriksson P. Kallin B, van 't Hooft FM. Båvenholm P. Hamsten A. Allelespecific increase in hasal transcription of the plasminogen-activator inhibitor 1 gene is associated with myocardial infarction. Proc Natl Acad Scl USA 1995: 92: 1851-1855.

22. Ye S. Green FR. Scarabin PY. Nicaud V. Bara L. Dawson SJ. Humphries SE, Evans A. Luc G. Cambou JP. Arveiler D. Henney AM. Cambien F. The $4 \mathrm{G} / 5 \mathrm{G}$ genetic polymorphism in the promoter of the plasminogen activator inhibitor-1 (PAI-1) gene is associated with differences in plasma PAI-1 activity but not with risk of myocardial infaretion in the ECTIM study. Thromb Hacmost 1995; 74 (3): 837-41.

23. Mansfield MW. Stickland MH, Grant PJ. PAI-1 concentrations in firstdegree relatives of patients with non-insulin dependent diabetes: metabolic and genetic associations. Thromb Haemost 1997: 77: 357-61

24. Henry M, Tregouc̈t DA, Alessi MC. Aillaud MF. Vis ikis S, Siest G, Tiret L, Juhan-Vague I. Metabolic determinants are much more important than genetıc polymorphisms in determining the PAI-1 activity and antigen plasma concentrations. A family study with part of the Stanislas cohort. Arterioscler Thromb Vasc Biol 1998: 18: 84-91.

25. Nordenhem A, Wiman B. Plasminogen activator inhibitor-1 (PAI-1) content in platelets from healthy individuals genotyped for the $4 \mathrm{G} / 5 \mathrm{G}$ polymorphism in the PAI-1 gene. Scand J Clin Lab Inv 1997; 57: 453-62.

26. Margaglione M, Grandone E, Vecchione G, Cappucci G, Giuliani N, Colaizzo D. Celentano E. Panico S. Di Minno G. Plasmınogen activator inhibitor-1 (PAI-1) antigen plasma levels in subjects attending a metabolic ward: relation to polymorphisms of PAI- 1 and angiotensin converting enzyme (ACE) genes. Arterioscler Thromb Vasc Bıol 1997: 17: 2082-7.

27. Margaglione M. Cappucci G, Colaizzo D, Giuliani N. Vecchione G. Grandone E. Pennell O. Di Minno G. The PAI-J gene locus $4 \mathrm{G} / 5 \mathrm{G}$ polymor- 
phism is associated with a family history of coronary heart disease. Arteroscler Thromb Vasc Biol 1998; 18: 152-6.

28. Doggen CJM, Manger Cats V, Bertina RM, Rosendaal FR. Interaction of coagulation defects and cardiovascular risk factors: increased risk of myocardial infarction associated with factor V Leiden or prothrombin $20210 \mathrm{~A}$. Circulation 1998; 97: 1037-41.

29. Miller SA, Dykes DD, Polesky HF. A simple salting out procedure for extracting DNA from human nucleated cells. Nucleic Acids Res 1988; 16: 1215 .

30. Klinger KW, Winquist R, Riccio A, Andreasen PA, Sartorio R, Nielsen LS, Stuart N, Stanislovitis P, Watkins P, Douglas R, Grzeschik K-H, Alitalo K, Blasi F, Dano K. Plasminogen activator inhibitor type 1 gene is located at region $\mathrm{q} 21.3-\mathrm{q} 22$ of chromosome 7 and genetically linked with cystic fibrosis. Proc Natl Acad Sci USA 1987; 84: 8548-52.

31. Woolf $B$. On estimating the relation between blood group and disease. Ann Hum Genet 1955; 19: 251-3.

32. Ridker PM, Hennekens CH, Lindpaintner K, Stampfer MJ, Miletich JP. Arterial and venous thrombosis is not associated with the $4 \mathrm{G} / 5 \mathrm{G}$ polymorphism in the promoter of the plasminogen activator inhibitor gene in a large cohort of US men. Circulation 1997; 95: 59-62.

33. Burzotta F, Di Castelnuovo A, Amore C, D'Orazio A, Donati MB, Iacoviello L. 4G/5G Polymorphism in the promoter region of the PAI- 1 gene is not a risk lactor for familial myocardial infarction in subjects over 45 years. Thromb Haemost 1997; 78: 1294-5.

34. Ossei-Gerning N, Mansfield MW, Stickland MH, Wilson IJ, Grant PJ. Plasmınogen activator inhibitor-I promoter $4 \mathrm{G} / 5 \mathrm{G}$ genotype and plasma levels in relation to a history of myocardial infarction in patients characterized by coronary angiography. Arterioscler Thromb Vasc Biol 1997; 17: 33-7.

35. Burzotta F, Di Castelnuovo A, Amore C, D’Orazio A, Di Bitondo R, Donati MB, Iacoviello L. 4G/5G Promoter PAI-1 gene polymorphism is asso- ciated with plasmatic PAI-1 activity in Italians: a model of gene-environment interaction. Thromb Haemost 1998; 79: 354-8.

36. Margaglione $M$, Cappucci $G$, d'Addedda $M$, Colaizzo $D$, Giuliani $N$, Vecchione G, Mascolo G, Grandone E, Di Minno G. PAI-1 plasma levels in a general population without clinical evidence of atherosclerosis. Relation to environmental and genetic determinants. Arterioscler Thromb Vasc Biol 1998; 18: 562-7.

37. Dawson SJ, Wiman B, Hamsten A, Green F, Henney AM, Humphries S. Allele specific differential binding of $\mathrm{HepG} 2$ nuclear extracts to a common polymorphism in the plasminogen activator inhibitor-1 (PAI-1) promoter which is associated with altered plasma PAI-1 levels. Thromb Haemost 1991; 65: 806.

38. Eriksson P, Nilsson L, Karpe F, Hamsten A. Very-low-density lipoprotein response element in the promoter region of the human plasminogen activator inhibitor-1 gene implicated in the impaired fibrinolysis of hypertriglyceridemia. Arterioscler Thromb Vasc Biol 1998; 18: 20-6.

39. Mansfield MW, Stickland MH, Grant PJ. Environmental and genetic factors in relation to elevated circulating levels of plasminogen activator inhibitor-1 in caucasian patients with non-insulin-dependent diabetes mellitus. Thromb Haemost 1995; 74: 842-7.

40. Henry M, Chomiki N, Scarabin PY, Alessi MC, Peiretti F, Arveiler D, Ferrières J, Evans A, Amouyel P, Poirier O, Cambien F, Juhan-Vague I. Five frequent polymorphisms of the PAI-1 gene. Lack of association between genotypes, PAI activity, and triglyceride levels in a healthy population. Arterioscler Thromb Vasc Biol 1997; 17: 851-8.

Received January 29, 1999 Accepted after revision March 2, 1999

\section{Ordering has never been so easy: http://www.schattaver.com}

